\title{
La prohibición de tratos inhumanos y degradantes en las detenciones policiales o de agentes del Estado en España ${ }^{* * * * * * *}$
}

\section{The prohibition of inhuman and degrading treatments in police detentions or from agents of the State in Spain}

\author{
RESUMEN
}

El presente análisis ofrece un panorama de la prohibición de tratos inhumanos y degradantes en las detenciones policiales o de agentes del Estado en España, teniendo en cuenta la posición del Tribunal Europeo de Derechos Humanos respecto de este tipo de prácticas y de la conducta de los agentes estatales españoles, principalmente en lo referente a la carencia de investigación y juzgamiento, lo que ha hecho necesario modificar el ordenamiento jurídico para evitar nuevas condenas.

PALABRAS CLAVE

Detenciones policiales, tortura, tratos inhumanos y degradantes, Tribunal Europeo de Derechos Humanos.

\section{ABSTRACT}

The present analysis envisions a panorama of the prohibition of inhuman and degrading treatment in the police arrests or from agents of the State in Spain, taking into account the position of the European Court of Human Rights in what has to do with this type of practices and the attitudes that have advanced

Abogado especialista en Derecho Administrativo de la Pontificia Universidad Javeriana y magíster en Derecho Público de la Universidad Carlos III de Madrid. Candidato a doctor en Derecho de la Universidad Carlos III de Madrid. Investigador independiente (Madrid, España). Contacto: ferchocisneros@hotmail.com ORCID ID: 0000-0003-0539-2958.

** $\quad$ Recibido el 11 de mayo de 2018, aprobado el 11 de junio de 2019.

Para citar el artículo: Cisneros Trujillo, C. La prohibición de tratos inhumanos y degradantes en las detenciones policiales o de agentes del Estado en España. En Revista Derecho del Estado, Universidad Externado de Colombia. N. ${ }^{\circ}$ 44, septiembre-diciembre de 2019, pp. 161-193. DOI: https://doi.org/10.18601/01229893.n44.07

*** El presente escrito es fruto de un trabajo de investigación realizado por el autor para optar al título de magíster en Derecho Público en la Universidad Carlos III de Madrid. 
the agents of the State, mainly in what has to do with the lack of investigation and prosecution by the Spanish Kingdom, relating to modify its legal system, influenced by the sentences suffered, which provoked a transformation and evolution aimed at curbing convictions for the complaints and lawsuits filed in the development of police arrests, mainly due to the lack of efficient investigation by the authorities.

\section{KEYWORDS}

Police Arrests, Torture, Inhuman and Degrading Treatment, European Court of Human Rights.

\section{SUMARIO}

Introducción. 1. Tortura, tratos inhumanos y tratos degradantes en el derecho internacional. 2. La prohibición de tratos inhumanos y degradantes y de la tortura en Europa. 3. Los deberes y obligaciones que surgen de la prohibición de tortura y tratos inhumanos y degradantes. 4. La prohibición de tratos inhumanos y degradantes en las detenciones policiales o de agentes del Estado en España. 4.1. La influencia de la jurisprudencia del TEDH en el ordenamiento jurídico español. 4.2. La prohibición frente a situaciones de incomunicación de los detenidos. 4.3. La relación con el derecho a la tutela judicial efectiva y el deber de investigación suficiente y efectiva. 4.3.1. Requisitos de la investigación. 4.3.2. Características de la investigación judicial en el marco de la tutela judicial efectiva. 4.3.3. Las decisiones judiciales de sobreseimiento de instrucciones penales y el derecho a la tutela judicial efectiva. Conclusiones. Referencias.

\section{INTRODUCCIÓN}

Históricamente la humanidad ha luchado y buscado la forma de obtener una protección de sus derechos, siempre con la evidencia de encontrarse en una situación o posición de inferioridad ante múltiples desigualdades que son propias o producto del desarrollo de las sociedades, las cuales deben ser erradicadas. Una de esas luchas ha sido, y sigue siendo, por el trato humano en condiciones de dignidad, relacionado con el Estado social de derecho, figura desarrollada principalmente en el siglo xx.

Justamente, después de varios siglos de historia, en la que llegó a constituir toda una institución, la comunidad internacional, a mediados del siglo pasado, alcanzó el consenso generalizado de que la tortura constituye una de las más graves violaciones de los derechos humanos y que supone un atentado directo contra la dignidad de la persona y los valores y principios sobre los que tiene asiento la democracia. Por lo anterior, la prohibición de 
la tortura y los malos tratos y tratos degradantes está reflejada en múltiples convenciones internacionales de derechos humanos de carácter universal y regional, así como en los textos constitucionales de la mayoría de los países democráticos.

La prohibición de la tortura en el derecho internacional es absoluta, de tal manera que esta conducta resulta inadmisible bajo cualquier circunstancia. La prohibición es tan fuerte y aceptada universalmente que se ha convertido en un principio fundamental del derecho internacional consuetudinario, es decir que incluso aquellos Estados que no han ratificado los tratados internacionales que prohíben explícitamente la tortura tienen proscrito aplicarla.

Una serie de pronunciamientos del Tribunal Europeo de Derechos Humanos (en adelante, TEDH o el Tribunal) han condenado a diferentes Estados por la vulneración del artículo 3 del Convenio Europeo de Derechos Humanos (en adelante, CEDH), para el caso de España desde el año 2004. A dichos pronunciamientos se une la gran cantidad de informes y recomendaciones, como los del Comité Europeo para la Prevención de la Tortura y de las Penas o Tratos Inhumanos o Degradantes, o del Comisario para los Derechos Humanos del Consejo de Europa, que dejan constancia de las evidencias de maltratos, principalmente a personas detenidas en manos de las fuerzas de seguridad del Estado, y de la necesidad de realizar mejoras para evitar este tipo de prácticas.

El ordenamiento jurídico español, influenciado por la evolución jurisprudencial del TEDH, se ha visto abocado a transformarse y evolucionar en procura de impedir condenas derivadas de las denuncias y demandas interpuestas con ocasión de las detenciones policiales, principalmente por la falta de investigación eficiente por parte de las autoridades.

Este escrito aborda la cuestión de la tortura en el contexto de las detenciones policiales en España con el objeto de dilucidar cuáles son los problemas estructurales que permiten que se den estas prácticas. En primer lugar, se explica la posición y la normativa del derecho internacional, para posteriormente enunciar la evolución de la jurisprudencia del TEDH, hacer referencia a sus pronunciamientos en los casos en que España ha sido demandada, y señalar su influencia en las sentencias del Tribunal Constitucional, principalmente en lo que respecta a las detenciones policiales; por último, se alude a la situación actual de estas prácticas en España.

\section{TORTURA, TRATOS INHUMANOS Y TRATOS DEGRADANTES EN EL DERECHO INTERNACIONAL}

El derecho internacional y de los derechos humanos establecen los límites y alcances del poder de los Estados sobre los individuos, e imponen obligaciones que los mismos deben cumplir, puesto que quienes suscriben y ratifican voluntariamente tratados y normas internacionales que reconocen y garantizan los 
derechos de las personas, se someten por ello mismo al control de organismos judiciales que reciben denuncias individuales. Desde la posición en que nos encontramos en el siglo XXI, con pocos Estados que admiten abiertamente la existencia de abusos a los derechos humanos, resulta difícil tener presente la naturaleza revolucionaria de los primeros tratados sobre el tema, cuando por primera vez el derecho internacional no solo gobernaba las relaciones entre los Estados sino también entre estos y los individuos; entonces, los Estados ya no podían argumentar, respecto de determinados actos, que la soberanía sobre su territorio prohibía toda intervención. El comportamiento y la actuación del Estado a nivel local quedaban sujetos a un control externo.

Dentro del derecho internacional se ha dado una evolución normativa en la materia. A mediados del siglo pasado, la tortura y los tratos inhumanos y degradantes constituían una de las más graves violaciones a los derechos humanos, toda vez que afectaban y atentaban seriamente contra principios propios de los Estados democráticos, como lo son los de la dignidad humana y el respeto por la integridad física y moral de las personas.

Esto se tradujo en la redacción del artículo 5 de la Declaración Universal de Derechos Humanos de 1948, donde se señala que "[n]adie será sometido a torturas ni a penas o tratos crueles, inhumanos o degradantes", destacándose que esta conducta constituye una forma de violencia y se entiende contraria a derecho por cuanto genera una afectación a la dignidad humana.

En el mismo sentido de la Declaración Universal de Derechos Humanos, el Pacto Internacional de Derechos Civiles y Políticos de 1966, en su artículo 7 , impone la prohibición de las torturas y de los tratos o penas crueles, inhumanos o degradantes, manifestando que "[n]adie será sometido a torturas ni a penas o tratos crueles, inhumanos o degradantes. En particular, nadie será sometido sin su libre consentimiento a experimentos médicos o científicos".

No obstante la expedición de dichas normas, el derecho internacional debía ser aún más sensible a esta problemática, y fue así como procedió al desarrollo normativo tomando en cuenta las obligaciones a cargo de los Estados de respetar y observar los derechos humanos, adoptando el 9 de diciembre de 1975, mediante Resolución 3452 de la Asamblea General de las Naciones Unidas, la Declaración sobre la Protección de Todas las Personas contra la Tortura y Otros Tratos o Penas Crueles, Inhumanos o Degradantes.

El artículo 1 de la Convención plasmó un primer acercamiento a lo que podemos entender actualmente como tortura, afirmando:

Se entenderá por el término tortura todo acto por el cual se inflija intencionadamente a una persona dolores o sufrimientos graves, ya sean físicos o mentales, con el fin de obtener de ella o de un tercero información o una confesión, de castigarla por un acto que haya cometido, o se sospeche que ha cometido, o de intimidar o coaccionar a esa persona o a otras, o por cualquier razón basada en cualquier tipo de discriminación, cuando dichos dolores o sufrimientos sean 
infligidos por un funcionario público u otra persona en el ejercicio de funciones públicas, a instigación suya, o con su consentimiento o aquiescencia ${ }^{1}$.

Esta prohibición ha sido considerada como absoluta e inderogable, y la Convención, en el artículo 2.2, manifiesta: "En ningún caso podrán invocarse circunstancias excepcionales tales como estado de guerra o amenaza de guerra, inestabilidad política interna o cualquier otra emergencia pública como justificación de la tortura", circunstancia que ha sido entendida por los tribunales internacionales de derechos humanos como una norma de ius cogens ${ }^{2}$.

Ahora bien, para algunos, como Pino Gamero, tal consideración "supone en la práctica que su reconocimiento jurídico es general y genera obligaciones erga omnes, lo que conlleva la obligación de todos los Estados de impedir la tortura y otras formas de malos tratos, abolirla y no respaldar, adoptar o reconocer actitudes que vulneren su prohibición"3; aunque los tratos o penas crueles, inhumanos o degradantes no siempre van acompañados de las mismas garantías que la tortura ${ }^{4}$. Es que no cabe duda de que difícilmente se encontrará un derecho que contenga tanta protección como el que se explica en el presente escrito ${ }^{5}$, puesto que la tortura es inadmisible bajo cualquier situación, incluyendo la guerra, la emergencia pública o circunstancias tan actuales como las amenazas terroristas. Esta prohibición ha tomado tanta fuerza y logrado tal aceptación que, como se dijo, al convertirse en un principio fundamental del derecho internacional consuetudinario, hasta los Estados que no han ratificado los tratados internacionales que prohíben expresamente la tortura tienen la obligación de no realizar estas conductas, y ello sin importar la persona, el lugar o la circunstancia.

En lo que respecta a la normatividad europea, el CEDH de 1950, en el artículo 3, establece: "Nadie podrá ser sometido a tortura ni a penas o tratos inhumanos o degradantes". Esta es la norma que ha servido de fundamento, tal como se verá en el presente escrito, para determinar las condenas a los Estados y adelantar la verificación del cumplimiento de las mismas, prin-

1 Convención contra la Tortura y Otros Tratos o Penas Crueles, Inhumanos o Degradantes, Adoptada y abierta a la firma, ratificación y adhesión por la Asamblea General en su resolución 39/46, de 10 de diciembre de 1984 Entrada en vigor el 26 de junio de 1987, de conformidad con el artículo 27.

2 Véase Quel López, J. y Fernández De Casadevante, C. La lucha contra la tortura (Aspectos de derecho internacional y de derecho interno español). Oñati: HAEE/IVAP, 1991, 29-33.

3 Pino Gamero, E. El sistema de prevención de la tortura del Protocolo Facultativo a la Convención contra la Tortura. En Universitas. Revista de Filosofía, Derecho y Política. N. ${ }^{\circ} 18,2013,3-39$.

4 Véase GonzÁlez GonzÁlez, R. El control internacional de la prohibición de la tortura y otros tratos o penas inhumanos y degradantes. Granada: Universidad de Granada, 1998, 67-68.

5 Así lo manifiesta Peter Kooijmans, Relator Especial de las Naciones Unidas sobre la Cuestión de la Tortura. Informe ante la Comisión de Derechos Humanos en su $48 .^{\circ}$ período de sesiones, 27 de diciembre de 1991 (E/CN.4/1992/17), par. 275. 
cipalmente en razón del análisis que se realiza por parte del Comité para la Prevención de la Tortura y de las Penas o Tratos Inhumanos o Degradantes, que fue creado mediante la Convención para la Prevención de la Tortura y de las Penas o Tratos Inhumanos o Degradantes, y por el TEDH, donde se ha desarrollado una jurisprudencia exhaustiva respecto de estas formas de abuso.

A pesar de lo anterior, que se puede entender como la máxima protección, y de la gran cantidad de organismos dedicados a la protección de los derechos relacionados con la prohibición de malos tratos y tratos degradantes, así como de la tortura ${ }^{6}$, no se ha impedido que en la realidad y en la práctica se presenten una gran cantidad de denuncias y condenas a los Estados por este tipo de conductas, realizadas al amparo del argumento de la lucha contra el terrorismo. Es por ello que se debe entrar a analizar las razones que fundamentan dichas condenas y los motivos por las cuales los Estados continúan realizando esos actos aun cuando estén prohibidos.

\section{LA PROHIBICIÓN DE TRATOS INHUMANOS Y DEGRADANTES Y DE LA TORTURA EN EUROPA}

Como se explicó en el acápite anterior, el artículo 3 del CEDH establece la prohibición de la tortura y otros tratos inhumanos y degradantes, y el TEDH ha desarrollado las definiciones y las distinciones entre los diferentes actos prohibidos.

El Caso Griego y el Caso de Irlanda c. Reino Unido ${ }^{8}$ son probablemente los principales pronunciamientos en los que se trató la distinción entre los actos prohibidos; en el primero, la Comisión Europea de Derechos Humanos adoptó un enfoque general que distinguía entre la "tortura", el trato "inhumano" y el "degradante". Este caso establece que la característica principal que define la tortura no es necesariamente la naturaleza o la gravedad del acto, sino el propósito con el que el mismo ha sido perpetrado, de tal manera que:

6 Para la profesora Pino, "de la amplia red de mecanismos de control y protección de derechos humanos, los más relevantes por lo que respecta a la prohibición de la tortura y los malos tratos son: en el ámbito de Naciones Unidas, el Comité contra la Tortura, el Relator Especial contra la Tortura y la Corte Internacional de Justicia; en el Sistema Europeo, el TEDH, el Comisario para los Derechos Humanos del Consejo de Europa y el Comité Europeo para la Prevención de la Tortura; en el Sistema Interamericano, la Comisión y la Corte Interamericanas de Derechos Humanos, y la Relatoría sobre los Derechos de las Personas Privadas de Libertad en las Américas; y, en el Sistema Africano, la Comisión Africana de Derechos Humanos y de los Pueblos, el Relator Especial sobre Cárceles y Condiciones de Detención, el Comité para la Prevención de la Tortura en África y la Corte Africana de los Derechos Humanos y de los Pueblos. Asimismo, ante ciertos tribunales internacionales puede exigirse la responsabilidad internacional de los individuos por la comisión de actos de tortura o de 'otros tratos' cuando constituyen un 'crimen de guerra' o un 'crimen contra la Humanidad'". PINO GAMERO. El sistema de prevención de la tortura del Protocolo Facultativo a la Convención contra la Tortura, cit., 3-39.

7 Comisión Europea de Derechos Humanos. El Caso Griego, 24 de enero de 1968.

8 TEDH. Caso Irlanda c. Reino Unido. Sentencia del 18 de enero de 1978. 
... todo caso de tortura debe ser un tipo de trato degradante e inhumano, al tiempo que el trato inhumano debe ser también degradante. La noción de trato inhumano cubre al menos aquel caso en el que el trato busque deliberadamente causar sufrimientos, ya sean mentales o físicos, que, en la situación en particular, sean injustificables [...] La tortura [...] tiene su propio objetivo, como puede ser la obtención de información o confesiones, o bien infligir algún tipo de pena, y suele tratarse, en general, de una forma agravada de trato inhumano. Los tratos o penas infligidos a un individuo pueden considerarse degradantes si se somete a este individuo a una grave humillación frente a terceros, o bien si se le obliga a actuar en contra de su voluntad o conciencia9.

No obstante lo anterior, en el Caso de Irlanda c. Reino Unido el TEDH realizó una distinción entre tortura, trato inhumano y trato degradante, y enunció que la diferenciación era necesaria dada la condición especial que implica la tortura, teniendo en cuenta que para que un acto sea considerado como tal debe generar un sufrimiento cruel y grave. El tribunal sostuvo que el realizar actos de sometimiento a privación del sueño, a posiciones de estrés, a privación de alimentos y bebida, a ruidos y al cubrimiento de la cabeza, tales como los que practicó en su momento el Reino Unido, generaron, "si no daños corporales reales, al menos sí sufrimiento mental y físico intenso [...] y también supusieron desequilibrios de carácter psiquiátrico durante los interrogatorios", constituyendo por tanto un trato inhumano, si bien no "ocasionaron un sufrimiento de la intensidad y la crueldad implícitas en la palabra tortura" ${ }^{10}$. Es así como el tribunal comienza a aplicar la distinción entre tortura y otras prácticas prohibidas, bajo el análisis subjetivo de la gravedad del sufrimiento padecido.

Por su parte, el trato inhumano puede definirse como aquel acto que no es lo suficientemente severo, o no contiene el elemento deliberado, para constituir tortura, pero que de todas formas cruza el umbral de gravedad máximo del trato degradante ${ }^{11}$. No obstante lo anterior, la jurisprudencia inicial ha establecido menores definiciones de trato inhumano; así, en el Caso Griego lo entendió como "aquel trato que cause deliberadamente un sufrimiento grave, ya sea mental o físico, que sea injustificable en la situación en particular" ${ }^{\prime 2}$, y a su vez en el Caso Irlanda c. Reino Unido expresó que "cualquier definición de las disposiciones del artículo 3 de la Convención debe comenzar por la noción de trato inhumano"13.

En lo que respecta a los tratos degradantes, en el Caso Griego se determinó que para que un acto sea considerado degradante debe implicar algún

9 Comisión Europea de Derechos Humanos. El Caso Griego, 24 de enero de 1968.

10 TEDH. Caso Irlanda c. Reino Unido. Sentencia del 18 de enero de 1978, par. 167.

11 Véase Evans, M.y Morgan, R. Preventing Torture. Oxford: Clarendon Press, 1998, 93.

12 Comisión Europea de Derechos Humanos. El Caso Griego, 24 de enero de 1968.

13 TEDH. Caso Irlanda c. Reino Unido. Sentencia del 18 de enero de 1978, par. 389. 
tipo de "humillación grave"14, de tal manera que se afecte la dignidad de una persona, y así lo reiteró el TEDH en pronunciamientos posteriores, como en el correspondiente al Caso East African Asians c. Reino Unido, donde expresó: "el propósito general de esta disposición es evitar interferencias particularmente graves con la dignidad del ser humano. De ahí se deduce que una acción que rebaje el rango, posición, reputación o carácter de una persona sólo puede considerarse 'trato degradante' en el sentido del artículo 3 , si alcanza un cierto nivel de gravedad" 15 .

Cabe resaltar que no puede establecerse una distinción entre los tres tipos de acto simplemente mediante una medición cruda del nivel de dolor o sufrimiento causado, puesto que la evaluación siempre será relativa y "dependerá de todas las circunstancias del caso, como la duración de los tratos, sus efectos físicos y mentales y, en algunos ejemplos, el sexo, edad y estado de salud de la víctima" 16 ; de tal manera que en un pronunciamiento reciente el tribunal manifestó que, si bien la gravedad del sufrimiento es una consideración significativa, "hay circunstancias en las que las pruebas reales de los efectos sobre la persona pueden no ser un factor principal a tener en cuenta" 17 .

Lo relevante para efectos del análisis de la conducta es verificar si esta se enmarca dentro de lo establecido por el artículo 3 del CEDH, en el entendido de que si tiene un mínimo de conducta se iniciaría bajo la modalidad de trato degradante, y una vez calificada la conducta, ya dependerá de cada caso en concreto y de la gravedad de los hechos cómo se cataloga; de acuerdo a esta distinción, el trato degradante que logra una gravedad determinada puede catalogarse como trato inhumano y, a su vez, si este es lo suficientemente serio puede ser redefinido como tortura ${ }^{18}$.

\section{LOS DEBERES Y OBLIGACIONES QUE SURGEN DE LA PROHIBICIÓN DE TORTURA Y TRATOS INHUMANOS Y DEGRADANTES}

El artículo 3 del CEDH debe ser, indiscutiblemente, el punto de partida de toda explicación que debamos realizar frente al tema del presente escrito. A pesar de que tiene una clara relación con el derecho a la vida, el cual se encuentra enmarcado en el artículo 2 del CEDH, el ordenamiento jurídico europeo establece mediante el artículo 3 una obligación autónoma e independiente, así el sujeto muera, en la cual los Estados no pueden someter o generar respecto de las personas actos que demuestren una forma de abuso encaminados hacia la tortura y los tratos inhumanos y degradantes.

14 Comisión Europea de Derechos Humanos. El Caso Griego, 24 de enero de 1968.

15 Comisión Europea de Derechos Humanos. Caso East African Asians c. Reino Unido. Informe de la Comisión del 14 de diciembre de 1973.

16 TEDH. Caso Irlanda c. Reino Unido. Sentencia del 18 de enero de 1978, par. 162.

17 TEDH. Caso Keenan c. Reino Unido. Sentencia del 3 de abril de 2001, par. 112.

18 Véase Evans y Morgan. Preventing Torture, cit., 82. 
Las obligaciones de los Estados son sustanciales y procedimentales. Las primeras frente a la prohibición de la conducta, las segundas respecto de la investigación de los actos. En cuanto a las sustanciales, la conducta prohibida consiste en infligir un sufrimiento físico o psíquico tendente, bien a humillar a la víctima ante los demás o ante sí misma (tratos degradantes), bien a doblegar su voluntad forzándola a actuar contra su conciencia (tratos inhumanos). Y en la forma más agravada y cruel de estos actos, que ya constituiría tortura, tal como lo vimos anteriormente, el TEDH ha sostenido que el artículo 3 del CEDH contiene una obligación de no hacer, la cual hace parte de las principales garantías de lo que se denomina orden público europeo, al punto que no admiten restricciones ni les es de aplicación ninguna de las circunstancias de excepción previstas en el artículo 15 del CEDH. Por regla general, el TEDH ha condenado a los Estados bajo esta vertiente en casos de particulares o actores privados por haber atentado contra la integridad de otros ciudadanos al interior de su jurisdicción, considerándose como actos enmarcados en la prohibición del artículo 3. En este sentido, en pronunciamientos como los del Caso A c. Reino Unido ${ }^{19}$, el Caso Z y otros c. Reino Unido ${ }^{20}$ o el Caso Pretty c. Reino Unido el tribunal expresó que el Estado tiene una obligación positiva que consiste en "suprimir o mitigar los daños, por ejemplo, evitando malos tratos por parte de organismos públicos o individuos privados o bien proporcionando condiciones mejoradas de asistencia [...] exigiría al Estado sancionar acciones destinadas a poner fin a una vida, una obligación que no puede derivarse del artículo 3"21.

En el segundo supuesto, se está frente a la obligación de investigar de forma eficaz las alegaciones de tortura y malos tratos, incluso aquellos cometidos por particulares, tal como se establece por parte del TEDH en el Caso Indelicato c. Italia ${ }^{22}$. En este caso se está ante obligaciones de hacer, es decir, de realizar actuaciones que procuren la protección de las personas frente a cualquier forma de abuso enmarcada en el artículo 3 del CEDH, dentro de las que encontramos el deber de una investigación eficaz, el deber de ofrecer garantías procesales y el deber de reparar y sancionar a los responsables. Estas son las razones por las que los Estados son mayormente condenados en el Sistema Europeo de Derechos Humanos, razón por la cual, a continuación, se explican de manera más detallada estos deberes.

El $\mathrm{TEDH}^{23}$ ha realizado una interpretación del CEDH que comporta avances considerables, principalmente en lo que tiene que ver con las sanciones a

19 TEDH. Caso A c. Reino Unido. Sentencia del 23 de septiembre de 1998.

20 TEDH. Caso Z y otros c. Reino Unido. Sentencia del 10 de mayo de 2001, par. 73. Véase también tedH. Caso E y otros c. Reino Unido. Sentencia del 26 de noviembre de 2002.

21 TEDH. Caso Pretty c. Reino Unido. Sentencia del 29 de abril de 2002.

22 TEDH. Caso Indelicato c. Italia. Sentencia del 18 de octubre de 2001.

23 TEDH. Caso Ribitsch c. Austria. Sentencia del 4 de diciembre de 1995, pars. 108-111. Véase también tedH. Caso Salman c. Turquía. Sentencia del 27 de junio de 2000; тEDH. Caso 
los Estados por la falta de investigación frente a las denuncias de maltrato, en especial por las grandes dificultades que supone probar la existencia de estos actos, circunstancia que determinó la aplicación por parte del ente investigador de medios probatorios que vayan "más allá de cualquier duda razonable" 24 para definir que el acto ha sucedido. De todas formas, es evidente que las víctimas, en la mayoría de los casos, no tienen forma de demostrar la ocurrencia de los hechos, situación que hace necesario invertir la carga de la prueba, de tal manera que será el Estado quien tenga que demostrar, al interior del proceso, que la vulneración no se generó; en este sentido concluyó el TEDH en el Caso Mammadov (Jalaloglu) c. Azerbaiján al afirmar:

Cuando los hechos son en su totalidad, o en gran parte, del exclusivo conocimiento de las autoridades, tal como ocurre con las personas que están bajo su control al ser detenidas, surgirá una presunción de hecho contundente respecto de las lesiones que ocurran durante la detención. De hecho, puede considerarse que la carga de la prueba de ofrecer una explicación satisfactoria y convincente recae sobre las autoridades ${ }^{25}$.

La investigación no se encuentra limitada al evento de presentación de una denuncia, debiendo los Estados adelantarla también cuando existan indicios que conduzcan a creer que ha podido presentarse una circunstancia de malos tratos o tortura. Justamente el TEDH ha expresado que "ante la ausencia de una denuncia expresa, debería llevarse a cabo una investigación si existen otros indicios lo suficientemente claros para creer que ha ocurrido un acto de tortura o malos tratos" 26 .

Respecto al deber de ofrecer garantías procesales, el $\mathrm{TEDH}^{27}$ ha manifestado que se encuentra directamente ligado a la investigación eficaz, puesto que la víctima debe tener acceso al procedimiento; la misma debe realizarse de manera inmediata, y las personas responsables de adelantarla deben ser independientes respecto de quienes son objeto de la investigación. Es de resaltar que estos

Aksoy c. Turquía. Sentencia del 18 de diciembre de 1996; TEDH. Caso Assenov y otros c. Bulgaria. Sentencia del 28 de octubre de 1998; тEDH. Caso Labita c. Italia. Sentencia del 6 de abril de 2000 ; y, más recientemente, TEDH. Caso Stefan Iliev c. Bulgaria. Sentencia del 10 de mayo de 2007.

24 Véase Tedh. Caso Irlanda c. Reino Unido. Sentencia del 18 de enero de 1978, par. 161.

25 TEDH. Caso Mammadov (Jalaloglu) c. Azerbaiján. Sentencia del 11 de enero de 2007, par. 62 .

26 TEDH. Caso Miembros de la Congregación de Testigos de Jehová de Gldani c. Georgia. Sentencia del 3 de mayo de 2007, par. 97.

27 Tedh. Caso Barbu Anghelescu c. Rumania. Sentencia del 5 de octubre de 2004, par. 66. Véase también TEDH. Caso Güle. c. Turquía. Sentencia del 27 de julio de 1998, pars. 81-82; TEDH. Caso Mikheyev c. Russia. Sentencia del 26 de enero de 2006; TEDH. Caso A c. Reino Unido. Sentencia del 23 de septiembre de 1998, par. 22. Véase también tedH. Caso Xe Y c. Países Bajos. Sentencia del 26 de marzo de 1985, pars. 21-27; тEDH. Caso Stubbings y otros c. Reino Unido. Sentencia del 22 de octubre de 1996, pars. 62-64. 
aspectos se aplican, como se enunció anteriormente, de manera explícita en aquellos casos en que se infligen malos tratos o torturas por particulares.

Frente al deber de reparar, el TEDH ha entendido que este no solo implica la compensación económica de los perjuicios ocasionados, sino que también comporta la introducción por parte del Estado de las modificaciones legales necesarias para impedir mayores perjuicios; así lo expresó el tribunal en el Caso Assanidze c. Georgia, en los siguientes términos:

... una sentencia en la que se determina la existencia de un incumplimiento impone al Estado demandado la obligación legal, en virtud del Artículo 46 del CEDH, de poner fin al incumplimiento y de reparar sus consecuencias de manera tal que se restablezca lo más posible la situación anterior al incumplimiento. $\mathrm{Si}$, por otro lado, la legislación nacional no permite la reparación, o sólo permite una reparación parcial, de las consecuencias del incumplimiento, el Artículo 41 permite al Tribunal otorgar a la parte perjudicada la reparación que estime conveniente. Esto significa, entre otras cosas, que una sentencia en la que el Tribunal determine la existencia de una violación al Convenio o a sus Protocolos impone al Estado demandado la obligación legal no sólo de pagar a los involucrados los montos otorgados como indemnización justa, sino también de elegir, sujeto a la supervisión del Comité de Ministros, las medidas generales o, si correspondiere, individuales que deberá adoptar su ordenamiento jurídico para poner fin a la violación sancionada por el Tribunal y de realizar toda posible reparación de sus consecuencias de manera tal que se restablezca en la medida de lo posible la situación anterior al incumplimiento ${ }^{28}$.

Como se puede observar, el TEDH, en aplicación del CEDH, ha realizado jurisprudencialmente grandes avances respecto de las obligaciones y deberes de los Estados Parte en desarrollo de la prohibición de tratos inhumanos o degradantes y de la tortura, principalmente en lo que concierne a la vertiente procesal, puesto que es una forma de prevenir la ocurrencia de este tipo de actos. A pesar de tratarse de obligaciones de medios y no de resultado, desafortunadamente las condenas a los Estados son numerosas, y España no es la excepción, principalmente en casos de detenciones de la policía o cuerpos equiparables, tal como lo veremos a continuación.

\section{LA PROHIBICIÓN DE TRATOS INHUMANOS Y DEGRADANTES}

EN LAS DETENCIONES POLICIALES O DE AGENTES DEL ESTADO EN ESPAÑA

El Reino de España no ha actuado de manera indiferente respecto a la prohibición de tratos inhumanos y degradantes y de torturas. El artículo 15 de la Constitución española establece: "Todos tienen derecho a la vida y a la

28 TEDH. Caso Assanidze c. Georgia. Sentencia del 8 de abril de 2004, par. 198. 
integridad física y moral, sin que, en ningún caso, puedan ser sometidos a tortura o a penas o tratos inhumanos o degradantes". A su vez, España es parte de seis de los siete principales tratados y protocolos referentes a la tortura y a la prohibición de tratos inhumanos y degradantes, así como de la Convención Europea sobre la Prevención de la Tortura y Otros Tratos o Penas Inhumanos o Degradantes, ratificada en 1989. Este conjunto de normas permiten deducir que la erradicación de estas conductas es una de las bases que fundan la dignidad y los derechos fundamentales en el Reino de España.

El TEDH, en el caso de las condiciones de detención ${ }^{29}$, ha considerado que los Estados tienen la obligación de garantizar circunstancias en favor de la dignidad humana de los sujetos, es decir que las condiciones y la forma de detención no conlleven angustias cuyo rango exceda el nivel inevitable de sufrimiento propio de la detención y que se asegure la atención médica necesaria ${ }^{30}$.

Cuando se analizan las 11 condenas proferidas por el TEDH en contra de España se encuentra que en todas se invocó el núcleo de la vertiente procesal de la prohibición que se explicó anteriormente, y 9 de ellos están relacionados con casos de detención incomunicada por delitos de terrorismo. El TEDH recuerda que cuando un individuo manifiesta de forma argumentada haber recibido o sufrido malos tratos de servicios como la policía o equiparables, el Estado debe garantizar una investigación oficial eficaz.

No obstante lo anterior, los estudios adelantados por la Comisión de Derechos Humanos y presentados al Consejo Económico y Social de la ONU, principalmente el recogido en el Informe del Relator Especial sobre la Cuestión de la Tortura, Theo van Boven, en el año 2004 $4^{[31]}$, han determinado la existencia de denuncias de torturas y tratos inhumanos y degradantes en el caso de detenciones a personas sindicadas de terrorismo. Principalmente se ha señalado la existencia de dificultades cuando se trata de detenciones incomunicadas, así como la afectación de las garantías procesales de los imputados, por la forma en que la ley de enjuiciamiento criminal ha adoptado la posibilidad de limitar ciertas facultades de las personas detenidas en casos de terrorismo.

29 Para algunos autores, como Moreno Catena, la detención es una medida cautelar personal que se puede adoptar antes de haberse iniciado el proceso penal como consecuencia de la comisión de un hecho delictivo, así como una vez iniciado el proceso penal si el investigado se fuga, e incluso si ya ha sido condenado. Véase Moreno Catena, V. Derecho procesal penal. Valencia: Tirant lo Blanch, 2004, 269.

30 TEDH. Caso Papon c. Francia. Sentencia del 7 de junio de 2001; тEDH. Caso Gelfmann c. Francia. Sentencia del 14 de diciembre de 2004.

31 Informe del Relator Especial sobre la Tortura, "Los derechos civiles y políticos, en particular las cuestiones relacionadas con la tortura y la detención”. Doc. E/CN.4/2004/56/Add.2, del 6 de febrero de 2004. 
Como se verá en el presente acápite, la jurisprudencia del TEDH ha tenido gran influencia en el actuar del Reino de España, modificando aspectos relativos a los informes médicos de los detenidos y evitando que los sujetos que realizaron la conducta sean juzgados por sus superiores. Así, ha habido cambios considerables en la posición del Tribunal Constitucional respecto a la prohibición contenida en el artículo 15 de la Constitución española, conduciendo a la adopción de mayores garantías de los detenidos y a eliminar actos que podrían catalogarse como inhumanos o degradantes.

A su vez, la jurisprudencia del Tribunal Constitucional español, tomando en cuenta lo planteado por el TEDH, ha formulado una línea clara respecto a la relación existente entre la prohibición de malos tratos o tratos degradantes y la tutela judicial efectiva, en el entendido de que se debe adelantar una investigación suficiente, eficaz y exhaustiva, agotando cuantas posibilidades de indagación resulten útiles para aclarar los hechos teniendo en cuenta las garantías de las personas que se encuentran en custodia del Estado.

Todos estos puntos serán considerados a continuación, empezando por analizar la influencia de la jurisprudencia del TEDH, los deberes de las autoridades en el caso de incomunicación de los detenidos, la relación e importancia del derecho a la tutela judicial efectiva en estos casos y cuando se considera que una investigación ha sido suficiente y efectiva.

\subsection{La influencia de la jurisprudencia del TEDH en el ordenamiento jurídico español}

El TEDH ha desarrollado, mediante diversos pronunciamientos, una posición frente a las condiciones de detención, puesto que ha considerado que en algunas circunstancias pueden ser fuente de violaciones al tantas veces mencionado en este escrito artículo 3 del CEDH. En el Caso Kudła c. Polonia el TEDH expresó:

... el Estado debe garantizar que una persona sea detenida en condiciones que son compatibles con su dignidad humana, que la manera y el método de ejecución de la medida no lo someta a una angustia y una penuria de tal intensidad que exceda el nivel inevitable de sufrimiento inherente a la detención y que, dadas las exigencias prácticas del encarcelamiento, su salud y su bienestar estén adecuadamente asegurados, entre otras cosas, por la atención médica necesaria ${ }^{32}$.

En otros casos, como Van der Ven c. Países Bajos, el tribunal ha señalado que "la práctica de realizar inspecciones que implican desnudar al detenido y que fue aplicada al denunciante durante aproximadamente tres años y medio

32 TEDH. Caso KudBa c. Polonia. Sentencia del 26 de octubre de 2000, par. 94. 
disminuyó su dignidad humana y debe haber dado lugar a sentimientos de angustia e inferioridad capaces de humillarlo y desmoralizarlo" ${ }_{33}$.

El progreso jurisprudencial del TEDH ha desarrollado una serie de obligaciones que son de medios, no de resultado; como mínimos requeridos con base en los compromisos adquiridos por parte de los Estados (entre los que se encuentra España), encontramos la obligación de investigar, de enjuiciar y de sancionar.

Respecto al deber de investigar, la jurisprudencia del TEDH ha expresado que ante denuncias de malos tratos como queja demostrable, sospecha razonable o afirmación defendible, ha exigido unos cánones de investigación que han de verse apoyados por pruebas pertinentes que fundamenten los hechos alegados; pruebas que pueden resultar de un cúmulo de indicios o de presunciones que hayan sido refutadas, suficientemente graves, precisas y concordantes. Estas pruebas han de circunscribirse en una investigación que cumpla con ciertos criterios básicos que vienen establecidos por el derecho internacional, como la exigencia de prontitud, la imparcialidad o la minuciosidad a la hora de investigar denuncias por tortura o malos tratos ${ }^{34}$.

En este punto es cuestionable lo referente a la imparcialidad en España, puesto que se cuestiona la independencia de las investigaciones, en tanto en cuanto quienes adelantan los trámites de las denuncias de tortura contra funcionarios de la policía son compañeros del mismo cuerpo de las fuerzas y de seguridad del Estado, procedimiento que pone en cuestionamiento la ecuanimidad ${ }^{35}$. Organismos no gubernamentales han opinado que la entidad encargada de investigar las denuncias de tortura del Ministerio del Interior no es independiente y han conminado al Gobierno a crear una agencia autónoma para investigar todas las denuncias de graves violaciones de derechos humanos cometidas por agentes del Estado ${ }^{36}$.

Respecto a la obligación de enjuiciar, consiste en que los Estados deben permitir la investigación de los culpables por la vía penal, civil o administrativa, sin promover la impunidad de los perjuicios graves contra la integridad física o moral de las personas que han sido objeto de detenciones policiales, en relación directa con el marco procedimental del artículo 3 del $\mathrm{CEDH}^{37}$.

33 TEDh. Caso Van der Ven c. Países Bajos. Sentencia del 4 de febrero de 2003, par. 62.

34 El TEDH se ha pronunciado al respecto en los casos Sevtap Veznedaroglu c. Turquía. Sentencia del 11 de abril de 2000; Kmetty c. Hungría. Sentencia del 16 de diciembre de 2003; Martínez Sala y otros c. España. Sentencia del 2 de noviembre de 2004; y Labita c. Italia. Sentencia del 6 de abril de 2000.

35 Quinto informe periódico de España, Comité de la Tortura, $43 .^{\circ}$ periodo de sesiones, de 5 de junio de 2010, 76 (Doc. СAT/C/SR.914).

36 Informe del Relator Especial sobre la Tortura, "Seguimiento dado a las recomendaciones del Relator Especial reflejadas en su informe sobre su visita a España en octubre de 2003". Doc. E/CN.4/2006/6/Add.2, del 21 de marzo de 2006, par. 288.

37 Véase, al respecto, tedH. Caso M.C.c.Bulgaria. Sentencia del 4 de diciembre de 2003; 
Finalmente, la obligación de sancionar consiste en que los Estados garanticen una condena y castigo con penas adecuadas, y que se impongan de acuerdo a la gravedad respecto de quienes cometieron los hechos prohibidos, además de conducir a que las víctimas tengan acceso a la reparación y a una indemnización justa y ajustada, conjuntamente con una rehabilitación.

Esta posición del TEDH llevó a condenar en 9 casos al Reino de España por considerar vulnerado el CEDH. En cuanto a situaciones de denuncias de torturas y malos tratos en régimen de detención incomunicada, encontramos los casos Martínez Sala y otros ${ }^{38}$, San Argimiro Isasa ${ }^{39}$, Beristain Ukar ${ }^{40}$, Otamendi Egiguren $^{41}$, Etxebarria Caballero ${ }^{42}$, Ataun Rojo ${ }^{43}$, Arratibel Garciandía ${ }^{44}$, Beortegui Martíne $z^{45}$ y, más recientemente, Igor Portu y Mattin Sarasola ${ }^{46}$. El TEDH ha manifestado enfáticamente que la prohibición de torturas y tratos inhumanos y degradantes es absoluta, cualesquiera que sean las conductas reprochables de las víctimas, y ha exhortado al Reino de España a tener en cuenta esta circunstancia para evitar futuras condenas. Cabe resaltar que las sentencias del Tribunal de Estrasburgo tienen carácter de cosa juzgada respecto del Estado demandado y deben ser interpretadas con efectos erga omnes.

Como aspecto general, el TEDH ha encontrado como situación común en todos los casos que quienes han padecido la tortura o los malos tratos o tratos degradantes eran sospechosos de pertenecer a una banda armada, y que muchos de los actos sucedieron durante los traslados y la incomunicación. En consecuencia, ha cuestionado la pasividad de las autoridades españolas para investigar los hechos denunciados, en tanto considera que se deben tener en cuenta las pruebas que determinen la importancia para esclarecer los hechos de tal manera que no pueden ser rechazadas de plano $^{47}$. Asimismo, ha puesto de presente las recomendaciones realizadas por el Comité para la Prevención de la Tortura a España, ante la negativa del Estado a implementarlas ${ }^{48}$. Estas recomendaciones consisten en la posibilidad para el detenido de entrevistarse con el abogado de su elección de manera inmediata, el derecho a ser reconocido

TEDH. Caso Okkalı c. Turquía. Sentencia del 17 de octubre de 2006; у тEDH. Caso Zeynep Özcan c. Turquía. Sentencia del 20 de febrero de 2007.

38 TEDH. Caso Martínez Sala y otros c. España. Sentencia del 2 de noviembre de 2004.

39 TEDH. Caso San Argimiro Isasa c. España. Sentencia del 28 de septiembre de 2010.

40 TEDH. Caso Beristain Ukar c. España. Sentencia del 8 de marzo de 2011.

41 TEDH. Caso Otamendi Egiguren c. España. Sentencia del 16 de octubre de 2012.

42 TEDH. Caso Etxebarria Caballero c. España. Sentencia del 7 de octubre de 2014.

43 TEDH. Caso Ataun Rojo c. España. Sentencia del 7 de octubre de 2014.

44 TEDH. Caso Arratibel Garciandía c. España. Sentencia del 5 de mayo de 2015.

45 TEDH. Caso Beortegui Martínez c. España. Sentencia del 31 de mayo de 2016.

46 TedH. Caso Igor Portu y Mattin Sarasola c. España. Sentencia del 13 de febrero de 2018 .

47 TEDH. Caso Martínez Sala y otros c. España. Sentencia del 2 de noviembre de 2004.

48 Informe del Relator Especial sobre la Tortura, "Los derechos civiles y políticos, en particular las cuestiones relacionadas con la tortura y la detención". Doc. E/CN.4/2004/56/Add.2, del 6 de febrero de 2004. 
por un médico de su elección, la comparecencia ante el juez para prorrogar la detención de 72 horas y la grabación de la detención incomunicada ${ }^{49}$.

Adicionalmente, la posición del TEDH ha generado una reacción en la jurisprudencia del Tribunal Constitucional español, puesto que con anterioridad al año 2007 se encuentran casos (del 2004 y anteriores) que hacen referencia a la obtención de pruebas mediante tratos inhumanos y degradantes, en donde se acude al recurso de amparo para alegar que la condena se produjo sobre la base de tales pruebas. Dicha alegación fue examinada por el Tribunal Constitucional, determinando este que a pesar de que la forma en que se adquirieron las pruebas no fue adecuada, existen otras que permitieron determinar su responsabilidad penal, no concediendo, por ese motivo, el amparo constitucional ${ }^{50}$.

Fue en el año 2007, en la STC 224/07, o en el 2008, en la STC 034/08, que se inició por el Tribunal Constitucional la interpretación del artículo 3 del CEDH, considerando que este es plenamente aplicable a la interpretación del artículo 15 de la Constitución española, y deduciendo incluso que coincide literalmente con aquel, y que tiene plena aplicación a la luz de lo establecido en el artículo 10.2 de la Constitución española que expresa: "Las normas relativas a los derechos fundamentales y a las libertades que la Constitución reconoce se interpretarán de conformidad con la Declaración Universal de Derechos Humanos y los tratados y acuerdos internacionales sobre las mismas materias ratificados por España". Esta posición ha sido sostenida incluso en las más recientes sentencias del Tribunal Constitucional STC 130/16 y STC 144/16.

A su vez, el tribunal ha sustentado en los casos Sevtap Veznedaroglu c. Turquía ${ }^{51}$, Assenov y otros c. Bulgaria ${ }^{52}$ y Kmetty c. Hungría ${ }^{53}$ aspectos relevantes frente a la investigación suficiente y efectiva en supuestos de denuncias sobre malos tratos y tratos degradantes en detenciones, tal como se explicará en el aparte correspondiente de este escrito.

Ciertamente, la jurisprudencia del TEDH y las condenas que ha recibido el Reino de España han conducido a un cambio de paradigma desde la perspectiva normativa, y parecería que en la práctica existe entre los agentes del Estado una mayor conciencia respecto de las consecuencias de actuar erróneamente o contraviniendo lo que les está legalmente permitido; además, la presión ante la posibilidad de una condena internacional conduce a que las instituciones públicas observen una conducta diferente, encaminada a evitar perjuicios y nuevas condenas.

49 TEDH. Caso Beristain Ukar c. España. Sentencia del 8 de marzo de 2011 y TEDH. Caso Otamendi Egiguren c. España. Sentencia del 16 de octubre de 2012.

50 sTC 7/2004, del 9 de febrero de 2004

51 теDH. Caso Sevtap Veznedaroglu c. Turquía. Sentencia del 11 de abril de 2000.

52 TEDH. Caso Assenov y otros c. Bulgaria. Sentencia del 28 de octubre de 1998.

53 TEDH. Caso Kmetty c. Hungría. Sentencia del 16 de diciembre de 2003. 


\subsection{La prohibición frente a situaciones de incomunicación de los detenidos}

Uno de los aspectos más discutidos y que mayor controversia han generado en lo que se refiere a la prohibición de tratos inhumanos y degradantes y de tortura es la forma como deben actuar las autoridades al momento de las detenciones incomunicadas, como medida cautelar ${ }^{54}$, puesto que, como lo manifiesta Montero Aroca, el privado de libertad tendrá (por regla general) derecho a comunicarse de forma oral, escrita y telefónica, es decir, tendrá derecho a un régimen de visitas y a la recepción de correspondencia y paquetes ${ }^{55}$.

Algunas legislaciones penales, como la española, permiten que las personas al momento de ser detenidas queden en circunstancias de incomunicación, principalmente en aquellos delitos considerados graves, para evitar que se obstruya la justicia o se destruya material probatorio relevante para el proceso. El Informe de Humans Rights Watch sobre medidas antiterroristas en España señala que la argumentación desarrollada por el Gobierno español para justificar su uso consistía en que "el recurso, bajo control judicial, a la incomunicación de algunos detenidos sigue siendo importante en el aspecto operativo, ya que evita que se puedan destruir pruebas o indicios relevantes, desaparezcan medios empleados en atentados, la huida de cómplices o colaboradores, todo lo cual sucedía en el pasado a causa de la colaboración criminal de abogados próximos al entorno de ETA" ${ }^{" 56}$.

En el caso de detenciones incomunicadas, medida que se debe interponer solo de manera excepcional con el propósito de salvaguardar la investigación cuando exista el riesgo de que se produzca la destrucción de pruebas o de que se pueda atentar contra bienes jurídicos de la víctima del delito, debe existir una mayor investigación de los hechos denunciados por parte del Estado. En las últimas sentencias el TEDH ha dado a entender que continuarán las condenas si no se modifica el régimen de incomunicación, y ello muy a pesar de los cambios introducidos al artículo 527 de la Ley de Enjuiciamiento Criminal, en lo que tiene que ver con el régimen de los derechos del detenido incomunicado ${ }^{57}$, puesto que el Reino de España no ha atendido por

54 Véase LÓPEZ YAGÜES, V. El derecho a la asistencia letrada (su ejercicio en situaciones de privación de libertad). Valencia: Universidad de Alicante, 2002; LóPEZ YaGÜES, V. La inviolabilidad de las comunicaciones con el abogado defensor. Valencia: Tirant lo Blanch, 2003.

55 Véase Montero Aroca, J.; Barona Vilar S. et al. Derecho jurisdiccional III. Proceso penal. Valencia: Tirant lo Blanch, 2015, 268.

56 Informe de Humans Rights Watch, “¿Sentando ejemplo? Medidas antiterroristas en España". Vol. 17, n. ${ }^{\circ}$ 1(D) 2005, 30; sobre las notas verbales de la Misión Permanente de España ante la ONU, p. 37.

57 Esta norma fue modificada atendiendo los requerimientos establecidos en la Directiva 2013/48 del Parlamento Europeo y del Consejo del 22 de octubre de 2013 sobre el derecho a la asistencia de letrado en los procesos penales y en los procedimientos relativos a la orden de detención europea, y sobre el derecho a que se informe a un tercero en el momento de la privación 
completo lo ordenado por el TEDH ni las recomendaciones realizadas por Amnistía Internacional. Lo anterior, pese a que la Ley de Enjuiciamiento Criminal fue modificada en el año $2015^{[58]}$ y ahora permite que la persona esté hasta 5 días incomunicada, prorrogables hasta por 5 días en el caso de delitos de terrorismo o banda armada, modificando lo que anteriormente se establecía frente a estos delitos, respecto de los cuales la incomunicación podía ser hasta por 13 días ${ }^{59}$.

Los estudios y análisis de las detenciones incomunicadas, principalmente elaborados por los organismos internacionales, han logrado determinar que su mayor duración en el tiempo puede generar condiciones propicias para la realización de torturas y malos tratos y tratos degradantes, porque en el periodo de incomunicación es cuando se producen amenazas, intentos de asfixia, agresiones, insultos, reducción de la alimentación y del sueño, lo que, tal como ha manifestado Amnistía Internacional, se considera como actos que llevan "a generar un clima de impunidad por los actos de tortura y malos tratos" $" 60$.

Por su parte, el Informe del Relator Especial sobre la Cuestión de la Tortura, Theo van Boven, en el año 2004, recomendó:

Como la detención incomunicada crea condiciones que facilitan la perpetración de la tortura y puede en sí constituir una forma de trato cruel, inhumano o degradante o incluso de tortura, el régimen de incomunicación se debería suprimir [...]. 67. Se debería garantizar con rapidez y eficacia a todas las personas detenidas por las

de libertad y a comunicarse con terceros y con autoridades consulares durante la privación de libertad (DOuE L 294/1 del 15 de febrero de 2012 p. 51). En esta norma se limitan al detenido o preso, de acuerdo a las circunstancias del caso, “a) Designar un abogado de su confianza. b) Comunicarse con todas o alguna de las personas con las que tenga derecho a hacerlo, salvo con la autoridad judicial, el Ministerio Fiscal y el Médico Forense. c) Entrevistarse reservadamente con su abogado. d) Acceder él o su abogado a las actuaciones, salvo a los elementos esenciales para poder impugnar la legalidad de la detención". Al respecto, el Consejo General del Poder Judicial, mediante informe al anteproyecto de ley orgánica de modificación de la Ley de Enjuiciamiento Criminal del 12 de enero de 2015, expresó: "cabría sostener que la fórmula empleada de limitación del derecho a la asistencia letrada y de los derechos de defensa presenta dudas de constitucionalidad. Conforme a esta argumentación, cabría sostener que el principio de proporcionalidad reclama que cuanto más se limite un derecho fundamental[,] más debe[n] exigirse razones de protección de otros derechos o intereses constitucionales".

58 El artículo 509 de la Ley de Enjuiciamiento Criminal expresa: "2. La incomunicación durará el tiempo estrictamente necesario para practicar con urgencia diligencias tendentes a evitar los peligros a que se refiere el apartado anterior. La incomunicación no podrá extenderse más allá de cinco días. En los casos en que la prisión se acuerde en causa por alguno de los delitos a que se refiere el artículo 384 bis u otros delitos cometidos concertadamente y de forma organizada por dos o más personas, la incomunicación podrá prorrogarse por otro plazo no superior a cinco días".

59 TEDH. Caso Ataun Rojo c. España. Sentencia del 7 de octubre de 2014, y tedH. Caso Arratibel Garciandía c. España. Sentencia del 5 de mayo de 2015.

60 Informe de Amnistía Internacional, "España: salir de las sombras. Es hora de poner fin a la detención en régimen de incomunicación”, de 2009 (EUR 41/001/2009), 7. 
fuerzas de seguridad a) el derecho de acceso a un abogado, incluido el derecho a consultar al abogado en privado; b) el derecho a ser examinadas por un médico de su elección, en la inteligencia de que ese examen podría hacerse en presencia de un médico forense designado por el Estado; y c) el derecho a informar a sus familiares del hecho y del lugar de su detención ${ }^{61}$.

Incluso el Comité Europeo de Prevención de la Tortura (CPT), desde el año 1991, ha expresado su preocupación por considerar excesivos los cinco días de incomunicación a los que son sometidos los detenidos ${ }^{62}$, principalmente en aspectos referentes a la posibilidad del detenido de entrevistarse con un abogado de manera inmediata; al reconocimiento médico, y a la comparecencia ante el juez para definir su situación jurídica en un plazo que no debería superar las 72 horas.

El TEDH ha tenido la oportunidad de pronunciarse respecto a este punto en diversas ocasiones, principalmente en relación con la aplicación del artículo 5.3 del CEDH que expresa: “Toda persona detenida [...] deberá ser conducida sin dilación a presencia de un juez o de otra autoridad habilitada por la ley para ejercer poderes judiciales, y tendrá derecho a ser juzgada en un plazo razonable o a ser puesta en libertad durante el procedimiento. La puesta en libertad puede ser condicionada a una garantía que asegure la comparecencia del interesado a juicio"63.

En el Caso Aksoy c. Turquía, el TEDH expresó que "existían garantías insuficientes disponibles para el denunciante, que estuvo detenido durante un largo período de tiempo. En especial, el negarle acceso a un abogado, doctor, familiar o amigo y la ausencia de una posibilidad real de ser llevado ante un tribunal para determinar la legalidad de su detención demostraban que fue dejado a merced de quienes lo retuvieron" 64 .

La mayoría de los casos de condena a España por parte del TEDH se ha referido a casos de detención incomunicada. El tribunal inicia su cuestionamiento frente a la actitud del Reino de España en los casos Etxebarria Caballero $^{65}$ y Ataun Rojo ${ }^{66}$, tomando en cuenta las recomendaciones del Comité Europeo de Prevención de la Tortura (СРT) realizadas en 2011 y 2013, y manifiesta que se debería acabar con el régimen de detención incomunicada, dada la

61 Informe del Relator Especial sobre la Tortura, "Los derechos civiles y políticos, en particular las cuestiones relacionadas con la tortura y la detención". Doc. E/CN.4/2004/56/Add.2, del 6 de febrero de 2004.

62 Informe del Comité Europeo de Prevención de la Tortura sobre la primera visita a España efectuada del 1 al 12 de abril de 1991 (СPT/Inf (96) 9).

63 Así se sostiene en tedh. Caso Casos Orhan c. Turquía. Sentencia del 18 de junio de 2002, par. 369; Tedh. Caso Timurtaș c. Turquía. Sentencia del 13 de junio de 2000, par. 103; TEDH. Caso Çiçek c. Turquía. Sentencia del 27 de febrero de 2001, par. 164.

64 TEDH. Caso Aksoy c. Turquía. Sentencia del 18 de diciembre de 1996, par. 83.

65 TEDH. Caso Etxebarria Caballero c. España. Sentencia del 7 de octubre de 2014.

66 TEDH. Caso Ataun Rojo c. España. Sentencia del 7 de octubre de 2014. 
imposibilidad de garantizar los derechos ante posibles torturas o malos tratos, posición reiterada en los casos Arratibel Garciandia ${ }^{67}$, Beortegui Martínez ${ }^{68}$ e Igor Portu y Mattin Sarasola ${ }^{69}$, donde, como ya se recordó, ha dado a entender que continuarán las condenas si no se modifica el régimen de incomunicación, por cuanto el Reino de España no ha atendido de manera integral lo solicitado por el TEDH y los demás organismos internacionales.

Considero que, si bien es cierto la lucha contra el terrorismo aún continúa, y vienen ocurriendo casos de graves delitos relacionados con el mismo, la normatividad respecto a la posibilidad de una detención incomunicada está llamada a ser modificada, en el entendido de que la presión, tanto por parte del TEDH como de los diferentes organismos internacionales que se encargan de la protección contra la tortura y los malos tratos y tratos degradantes, ha conducido a que esta figura haya sido puesta en discusión; incluso, podría aspirarse a que la detención incomunicada se equipare a la general de la mayoría de los Estados de Europa, donde el tiempo de incomunicación no supera las 48 horas, toda vez que un plazo mayor no resulta justificable y permite garantizar la reducción de los casos de tortura o malos tratos y tratos degradantes, aunque ponga en riesgo de alguna forma la investigación.

\subsection{La relación con el derecho a la tutela judicial efectiva y el deber de investigación suficiente y efectiva}

Uno de los aspectos más relevantes de la prohibición de las torturas y los malos tratos y tratos degradantes es la relación que tiene con otros derechos que se pueden ver vulnerados en los casos que se cometen este tipo de conductas, dentro del que encontramos la tutela judicial efectiva, concerniente principalmente con el deber que tienen los Estados de adelantar una investigación suficiente y objetiva frente a las denuncias que se formulan sobre este tipo de hechos.

El Informe del Relator Especial sobre la Cuestión de la Tortura, Theo van Boven, de 2004, solicitó información respecto a este aspecto y señaló:

Según una comunicación de octubre de 2003, actualizada por otra comunicación de 25 de noviembre de 2003, entre 1997 y 2003 el Tribunal Supremo dictó 35 sentencias relacionadas con la tortura: 13 absolutorias y 22 condenatorias $(7$ de ellas se referían a la tortura de presuntos terroristas). De las 22 sentencias condenatorias, 6 fueron por lesiones y 16 por tortura $(8$ contra miembros de la

67 TEDH. Caso Arratibel Garciandía c. España. Sentencia del 5 de mayo de 2015.

68 TEDH. Caso Beortegui Martínez c. España. Sentencia del 31 de mayo de 2016.

69 TEDH. Caso Igor Portu y Mattin Sarasola c. España. Sentencia del 13 de febrero de 2018 . 
Policía Nacional, 4 contra miembros de la Guardia Civil, 1 contra la policía local, 1 contra las autoridades penitenciaras y 1 contra otras personas $)^{70}$.

Ante este panorama, que no parece nada alentador, el Relator recomendó:

Las denuncias e informes de tortura y malos tratos deberían ser investigados con prontitud y eficacia. Se deberían tomar medidas legales contra los funcionarios públicos implicados, que deberían ser suspendidos de sus funciones hasta conocerse el resultado de la investigación y de las diligencias jurídicas o disciplinarias posteriores. Las investigaciones se deberían llevar a cabo con independencia de los presuntos autores y de la organización a la que sirven. Las investigaciones se deberían realizar de conformidad con los Principios relativos a la investigación y documentación eficaces de la tortura y otros tratos o penas crueles, inhumanos o degradantes, adoptados por la Asamblea General en su resolución 55/89[71].

El TEDH en el caso de España ha encontrado falencias en la forma y mecanismos en que se han adelantado las investigaciones, y justamente por esta razón ha sido condenado debido al incumplimiento de los estándares mínimos que debe contener la vertiente procesal de la prohibición de torturas y malos tratos y tratos degradantes. En el Caso Martínez Sala consagra dos principios, por un lado la investigación debe ser capaz de determinar si el uso de la fuerza ha estado justificada; y por otro deben usarse todos aquellos medios que aseguren un análisis detallado y objetivo del incidente ${ }^{72}$.

Esto pronunciamiento fue tomado en cuenta por el Tribunal Constitucional, quien determinó la existencia de una relación directa entre la prohibición contenida en el Artículo 15 de la Constitución Española y el derecho a la tutela judicial efectiva que se encuentra en el Artículo 24.1 que expresa "1. Todas las personas tienen derecho a obtener la tutela efectiva de los jueces y tribunales en el ejercicio de sus derechos e intereses legítimos, sin que, en ningún caso, pueda producirse indefensión". No podemos dejar de lado que estamos en estos casos ante decisiones judiciales especialmente cualificadas en función del derecho material sobre el que recaen, por ello el Tribunal Constitucional como garante último de los derechos fundamentales a través del recurso de amparo, no puede resultarle indiferente aquella cualificación cuando se impugnan ante él este tipo de resoluciones, pues no sólo se encuentra en juego este derecho, sino que puede producirse un efecto derivado o reflejo sobre la reparación del derecho fundamental cuya invocación sostenía la pretensión

70 Informe del Relator Especial sobre la Tortura, "Los derechos civiles y políticos, en particular las cuestiones relacionadas con la tortura y la detención”. Doc. E/CN.4/2004/56/Add.2, del 6 de febrero de 2004, 12.

71 Ibíd., 18.

72 TEDH. Caso Martínez Sala y otros c. España. Sentencia del 2 de noviembre de 2004. 
ante el órgano judicial, con independencia de que la declaración de la lesión sea sólo una de las hipótesis posibles ${ }^{73}$.

El Tribunal Constitucional ha entendido que este derecho se satisface con una investigación suficiente y efectiva, donde se indague lo acontecido, para lo cual a modo de ejemplo en la Sentencia $130 / 16^{74}$ toma en cuenta la jurisprudencia del TEDH, para quien ha manifestado en algunas de sus sentencias que sin una indagación oficial efectiva la prohibición general de tortura y de trato y castigo inhumano y degradante, a pesar de su importancia fundamental, sería ineficaz en la práctica y en algunos casos los agentes del Estado podrían abusar de los derechos de aquellos bajo su control con total impunidad ${ }^{75}$.

La investigación debe cumplir una serie de estándares y requisitos en estos casos, los cuales han sido desarrollados por los pronunciamientos del Tribunal Constitucional, estableciendo dentro de la vertiente procesal de la prohibición de la tortura y de los tratos inhumanos y degradantes, unas características especiales que la hacen diferente a las demás y las decisiones judiciales deben contener una motivación suficiente para considerar el sobreseimiento del proceso, elementos que explicaremos a continuación.

\subsubsection{Requisitos de la investigación}

La investigación debe consagrar y establecer situaciones especiales frente a la tutela judicial efectiva, en el entendido que nos encontramos con derechos relacionados directamente con la dignidad humana, como es el caso de la integridad física de quienes están bajo la custodia y protección de los organismos del Estado. Con base en esto, los requisitos que debe tener todo procedimiento son un razonamiento jurídico, motivación coherente y suficiente.

Por lo anterior, la jurisprudencia del Tribunal Constitucional en la sentencia STC 224/2007 de 22 de octubre, expresa que "el denunciante que, como ofendido, promueve la actividad jurisdiccional tiene derecho a una respuesta judicial razonada, que bien puede ser el sobreseimiento o archivo de las actuaciones" 76 , de tal manera que al interior de las investigaciones, se deben analizar las circunstancias de hecho y de derecho que llevan a adelantar esas actuaciones, y argumentar razonablemente las decisiones que se adoptan al interior del proceso judicial. Esta motivación debe ser acorde con la prohibición absoluta de las conductas de tortura y malos tratos y tratos degradantes, al punto que ha de tener en cuenta la gravedad de la quiebra

73 stc 034 de 2008 , del 25 de febrero.

74 STC 130/16, del 18 de julio.

75 TEDH. Caso Sevtap Veznedaroglu c. Turquía. Sentencia de 11 de abril de 2000; TEDH. Caso Assenov y otros c. Bulgaria. Sentencia del 28 de octubre de 1998; TEDH. Caso Kmetty c. Hungría. Sentencia del 16 de diciembre de 2003.

76 STC 224/2007, del 22 de octubre, f. j. 3. 
de esta proscripción y el tipo de actividad judicial necesaria para preservarla dada su especial dependencia respecto de dicha actividad judicial de la indemnidad de la dignidad de la persona, objeto central de protección de la contravención ${ }^{77}$.

Pero además la motivación debe ser reforzada, lo que la profesora Villalibre Fernández ha entendido como aquella que "no comporta la apertura de la instrucción siempre, ni impide la clausura temprana de la misma; tampoco impone la realización de todas las diligencias de investigación posibles o propuestas. Se trata en este contexto de agotar cuantas posibilidades razonables de indagación resulten útiles para aclarar los hechos, aunque esta cuestión será analizada con mayor detalle en un apartado posterior"78, así por ejemplo en la sentencia STC 012/13 el Tribunal Constitucional consideró que debía negarse el recurso de amparo en el entendido que se no se vulneró derecho alguno, y se actuó de conformidad con la doctrina constitucional, toda vez se realizó la investigación teniendo en cuenta los medios razonables para determinar lo acontecido, a pesar de lo anterior tuvo 2 votos particulares, donde se pone de presente las razones que llevan a apartarse de la decisión mayoritaria argumentando que no se adelantó una investigación acorde a las condiciones plasmadas en la doctrina constitucional frente al tema analizado.

Como se puede concluir de la argumentación sostenida anteriormente, se trata de una protección judicial doblemente reforzada que no encuentra relación de igualdad a otras demandas de protección judicial, pues en estos casos se solicita la protección frente a la vulneración de un derecho fundamental, que constituye un derecho absoluto cuya indemnidad depende esencialmente de dicha tutela judicial ${ }^{79}$.

\subsubsection{Características de la investigación judicial en el marco} de la tutela judicial efectiva

El Tribunal Constitucional ha desarrollado mediante su jurisprudencia unas condiciones propias de las investigaciones que se adelanten en contexto con una denuncia referente a la prohibición de tortura, malos tratos y tratos degradantes que afecte la integridad física y moral de los detenidos, considerando que la misma se debe llevar a cabo de manera suficiente, pronta, efectiva y eficaz.

Como se vio en el apartado anterior, la garantía de las investigaciones en desarrollo de la tutela judicial efectiva está dada también por que las

77 STC 34/2008, del 25 de febrero, f. j. 6.

78 Villalibre Fernández, V. Confluencia del derecho a la tutela judicial efectiva con el concepto de investigación oficial eficaz en el contexto de la prohibición de la tortura. En Foro, nueva época. Vol. 15, n. ${ }^{\circ}$ 1, 2012, 29-86. DOI: 10.5209/rev_FORO.2012.v15.n1.39582.

79 SSTC 34/2008, del 25 de febrero, f. j. 4 , y sTC 52/2008, del 14 de abril, f. j. 2. 
decisiones que se adopten al interior del proceso estén conforme y encaminadas con el derecho que se protege en el fondo, el cual es a no sufrir tratos inhumanos y denigrantes.

Mediante la sentencia STC 069/2008, de 23 de junio ${ }^{80}$, el Tribunal Constitucional puso de manifiesto que las sospechas sobre la efectiva realidad de los hechos denunciados pueden no ser contundentes, pero que lo que importa desde la perspectiva constitucional en los casos relacionados con el artículo 15 de la Constitución española es si son idóneos para que deba proseguirse en la indagación judicial llevada a cabo, en la medida en que aún se cuente con medios de investigación para ello; esta es la forma en que se entiende la característica de suficiente que debe tener la investigación, puesto que la gravedad de los hechos que son objeto de análisis merece resolverse mediante criterios objetivos, de tal manera que no solo se debe tener en cuenta el material probatorio aportado al inicio del procedimiento, sino que se pueden exigir nuevas diligencias que en otro tipo de caso serían innecesarias ${ }^{81}$.

Por otro lado, si bien es cierto que la jurisprudencia del Tribunal Constitucional, como lo expresa Villalibre Fernández:

... utiliza indistintamente el adjetivo de "efectiva" y [el] de "eficaz" para hacer referencia a una de las propiedades que debe reunir toda investigación judicial en este contexto. Las dos aluden a la capacidad de lograr el efecto que se desea o se espera, aunque la efectividad evoca más específicamente la realización real y verdadera de una acción, en nuestro caso, el llevar a cabo una investigación judicial de acuerdo con el art. 24.1 CE en relación con la prohibición de la tortura y otros tratos o penas crueles, inhumanos o degradantes ${ }^{82}$,

en lo que respecta a la prohibición de malos tratos y tratos degradantes, la eficacia de las investigaciones se ve agotada en el momento en que se exponen de manera concreta y justificada las razones que llevan al cierre de la misma y en que se superan las circunstancias que evidenciaban una sospecha acerca de los hechos denunciados ${ }^{83}$.

La eficacia de la investigación debe tener una relación con la forma en que actúa también el denunciante, puesto que este debe ejercer su derecho a poner en conocimiento de las autoridades su denuncia en un plazo razonable, de tal manera que su demora o tardío actuar podría afectar el desarrollo de aquella, y luego no podría desplegarse de manera adecuada puesto que existiría una falta de credibilidad en la denuncia formulada. A contrario sensu, el Tribunal Constitucional ha establecido que no resultaría razonable inferir

80 STC 069/2008 del 23 de junio, f. j. 3.

81 STC 34/2008, del 25 de febrero, f. j. 4.

82 Villalibre Fernández. Confluencia del derecho a la tutela judicial efectiva con el concepto de investigación oficial eficaz en el contexto de la prohibición de la tortura, cit.

83 sTC 063/2008, del 26 de mayo, f. j. 3. 
la falta de objetividad de la acusación en el caso en que hayan transcurrido menos de dos meses entre la presunta realización de los hechos denunciados y la interposición de la misma ${ }^{84}$.

Por otro lado, el Tribunal Constitucional ha dejado claro que la eficacia está relacionada con el archivo de las diligencias donde no hayan sido esclarecidas suficientemente las circunstancias fácticas denunciadas y existen aún medios razonablemente disponibles para despejar las posibles dudas al respecto ${ }^{85}$.

En lo que concierne a la prontitud, el Tribunal Constitucional, en la sentencia STC 034/2008, afirmó que "frente a la denuncia de tratos policiales inhumanos o degradantes por parte del detenido no se produjo una investigación judicial eficaz y que, aunque se emprendió prontamente la investigación judicial y tuvo cierto contenido, se clausuró cuando existían aún sospechas razonables acerca de la posibilidad de que el delito se hubiera cometido" 86 . De lo anterior se deduce que una investigación judicial puede realizarse con prontitud y puede considerarse como ineficaz, situación que va en contravía de las condiciones y características propias de la misma.

Por último, la jurisprudencia del Tribunal Constitucional ha adoptado la figura de la investigación oficial eficaz, característica especial para este tipo de circunstancias desarrollada por el $\mathrm{TEDH}^{87}$. A pesar de que en la sentencia STC $224 / 2007^{[88]}$ se enuncia que la obligación de realizar una indagación oficial eficaz hace referencia a poder llegar a identificar y castigar a los responsables de las conductas prohibidas de malos tratos y tratos degradantes, se considera que al rechazar todas o algunas de las peticiones de diligencias presentadas por quienes denuncian unos malos tratos policiales, se les puede privar de la posibilidad razonable de esclarecer los hechos denunciados por ausencia de una exploración profunda y efectiva; situación que de alguna manera resulta excesivamente garantista, puesto que en algunos casos será procedente no tener en cuenta ciertos medios probatorios por no resultar relevantes; así, en cada caso deberá analizarse en concreto si la solicitud formulada es adecuada, conducente y aporta al procedimiento adelantado, pues la característica de oficial y eficaz no puede derivar en una obligación de resultado, en el entendido de que siempre exista un sancionado, sino que debe ser de medios, pues una vez evacuadas y valoradas todas las pruebas se puede determinar irrefutablemente quiénes fueron los responsables e imponerles las sanciones pertinentes.

84 STC 063/2010, del 18 de octubre, f. j. 3 .

85 SSTC 107/2008, del 22 de septiembre, f. j. 4, y 40/2010, del 19 de julio, f. j. 4.

86 STC 34/2008, del 25 de febrero, f. j. 9.

87 TEDH. Caso Sevtap Veznedaroglu c. Turquía. Sentencia del 11 de abril de 2000; TEDH. Caso Kmetty c. Hungría. Sentencia del 16 de diciembre de 2003; y tedH. Caso Martínez Sala y otros c. España. Sentencia del 2 de noviembre de 2004.

88 STC 224/2007, del 22 de octubre, f. j. 3. 
Para concluir, la tutela judicial se considera suficiente y efectiva, de conformidad con los derechos que involucra la prohibición de malos tratos y tratos degradantes, si se ha producido una investigación donde se revelaba necesaria, de tal manera que esta exigencia no comporta la apertura de la instrucción en todo caso, ni impide la clausura temprana de la misma; por el contrario, vulnera el derecho en este ámbito que no se abra o que se clausure la instrucción cuando existan sospechas razonables de que puede haberse cometido el delito de torturas o de tratos inhumanos o degradantes denunciado, y cuando tales sospechas se revelen como susceptibles de ser despejadas ${ }^{89}$.

4.3.3. Las decisiones judiciales de sobreseimiento de instrucciones penales y el derecho a la tutela judicial efectiva

Al momento de analizar si la investigación ha atendido los requisitos señalados en el presente escrito se deben tener en cuenta otros aspectos importantes que la jurisprudencia del Tribunal Constitucional ha desarrollado, como son la existencia de sospechas razonables de que puede haberse cometido el delito de torturas o de tratos inhumanos o degradantes que ha sido denunciado; por otro lado, es necesario verificar si los órganos judiciales han agotado todos los medios de indagación que se consideran prudentes y que se encuentran a su alcance para desmentir o confirmar la credibilidad de la denuncia de dichas conductas prohibidas.

A su vez, a los Estados, al momento de adelantar las investigaciones referentes a torturas o malos tratos y tratos degradantes en detenciones policiales, les corresponde seguir una serie de parámetros. En primer lugar, deben analizarse los exámenes e informes médicos que se realizan en el momento en que la persona es detenida; en segundo lugar, hay que respetar la posibilidad que tienen los denunciantes de presentar medios probatorios al interior de la denuncia; en tercer lugar, es preciso respetar las circunstancias que llevan al archivo o sobreseimiento y las posibilidades que se tienen para acudir ante el Tribunal Constitucional.

Las condiciones de calificación que se viene de señalar están íntimamente relacionados puesto que, en las investigaciones que contienen sospechas o indicios de tortura o tratos crueles, inhumanos o degradantes padecidos bajo la custodia de autoridades policiales, de la normatividad que proscribe este tipo de conductas se concluye una orden cualificada de agotar cuantas posibilidades prudentes de indagación resulten útiles para aclarar los hechos ${ }^{90}$.

89 STC 34/2008, del 25 de febrero, f. j. 6.; 107/2008, del 22 de septiembre,f.j. 2, y 123/2008, del 20 de octubre, f. j. 2.

90 STC 224/2007, del 22 de octubre, f. j. 3; 34/2008, del 25 de febrero, f. j. 6., y 107/2008, del 22 de septiembre, f. j. 2. 
La situación de sospechas razonables ha sido desarrollada por el Tribunal Constitucional teniendo en cuenta lo estipulado por el artículo 15 de la Constitución española, y al respecto se pronuncia Villalibre Fernández afirmando que esta figura:

... se concreta esencialmente en los siguientes fundamentos: la escasez del acervo probatorio ha de alentar la diligencia del instructor para la práctica efectiva de las medidas posibles de investigación; la desigualdad de armas, que deriva de la situación psicológica del denunciante y de la cualificación oficial de los denunciados, debe compensarse con la firmeza judicial, y, finalmente, ha de considerarse como medio de indagación particularmente idóneo de este tipo de denuncias la valoración del testimonio judicial del denunciante ${ }^{91}$.

Para llegar a esta conclusión se tienen en cuenta los pronunciamientos del Tribunal Constitucional en las sentencias STC 52/2008, de 14 de abril ${ }^{92}$, y STC 107/2008, de 22 de septiembre ${ }^{93}$, donde se deja claro que la concesión o negación del amparo dependerá de cada caso en concreto y de la forma como actúa el denunciante, así como del material probatorio con que se cuenta. Al respecto, la jurisprudencia constitucional tuvo oportunidad de afirmar:

Una vez alcanzada la convicción judicial sobre la falta de veracidad de los hechos denunciados, es claro que se está ante uno de los supuestos de falta de persistencia de sospechas razonables. E incluso, aunque pudiera sostenerse que persistían dichas sospechas, se estaría en uno de los supuestos en que se han agotado los medios razonables y eficaces de investigación, toda vez que, teniendo en cuenta que los únicos medios de investigación que en este amparo se han concretado como relevantes por parte de la recurrente han sido su propia declaración y la identificación y declaración de los agentes intervinientes en la detención e interrogatorios, en las resoluciones judiciales impugnadas se da cumplida respuesta a la falta de eficacia que tendría cualquiera de ambos medios de instrucción ${ }^{94}$.

Por lo anterior es importante tener en cuenta que la tutela judicial del derecho a no sufrir torturas ni tratos inhumanos o degradantes puede exigir que se inicie o avance en una indagación allí donde quizás en otro tipo de supuestos podría advertirse una base insuficiente ${ }^{95}$. Pero para preservar esta investigación

91 Villalibre Fernández. Confluencia del derecho a la tutela judicial efectiva con el concepto de investigación oficial eficaz en el contexto de la prohibición de la tortura, cit., 42.

92 F. j. 2.

93 F. j. 2.

94 STC 063/2008, del 26 de mayo, f. j. 4.

95 Así se han enunciado y se han establecido figuras como "queja demostrable" (TEDH. Caso Sevtap Veznedaroglu c. Turquía. Sentencia del 11 de abril de 2000), "sospecha razonable" (TEDH. Caso Kmetty c. Hungría. Sentencia del 16 de diciembre de 2003) y "afirmación defendible" (TEDH. Caso Martínez Sala y otros c. España. Sentencia del 2 de noviembre de 2004), utilizadas por 
es necesario que el denunciante aporte alguna prueba, la solicite o ponga de manifiesto algún indicio que demuestre efectivamente su existencia, de tal manera que el juez se vería obligado a preservar la investigación en aquellos casos donde se encuentre una sospecha que indique la existencia de dichos actos prohibidos. Justamente, esta fue la razón para que el Tribunal Constitucional concediera los recursos de amparo en las sentencias STC 224/2007 ${ }^{[96]}$, $34 / 2008^{[97]}, 52 / 2008^{[98]}, 69 / 2008^{[99]}$ y $107 / 2008^{[100]}$, entendiendo que existían dudas razonables acerca de la posible comisión de los hechos denunciados, tomando como base indicios relacionados directamente con la ocurrencia de torturas o malos tratos, aspecto suficiente para obligar al juez a perseverar en la indagación de lo sucedido y no decretar el sobreseimiento de la instrucción; circunstancia diferente a la observada en la sentencia STC 123/2008, de 20 de octubre, donde ni se aporta junto con la denuncia indicio objetivo alguno que permita considerar la existencia de una sospecha razonable de torturas o malos tratos durante la detención, ni se proponen diligencias probatorias a partir de las cuales se pueda obtener o recaudar evidencias que aporten en la denuncia, caso en el cual la procedencia del sobreseimiento del proceso resulta totalmente adecuada.

Por otro lado, se constituye en una vulneración del derecho a la tutela judicial efectiva si se clausura una investigación existiendo medios de indagación disponibles para despejar la continuidad de sospechas razonables sobre la comisión de torturas o tratos inhumanos o degradantes. Esto conduce a que el procedimiento judicial no sea eficaz y, por tanto, no se reúnan los requisitos exigidos por la jurisprudencia constitucional ${ }^{101}$, así como también sería una vulneración que el órgano judicial deniegue la práctica de pruebas sin fundamento alguno ${ }^{102}$. Conforme las exigencias del mismo Tribunal Constitucional, los medios deben ser oportunos, adecuados, pertinentes e idóneos para conducir al esclarecimiento de los hechos denunciados.

Como podemos observar, el Tribunal Constitucional ha desarrollado una posición clara en el entendido de que los casos en que se decida archivar los procesos deben cumplir una serie de requisitos estrictos, no solo en razón de los derechos que están en juego, sino para promover una actuación mayormente proactiva y conducente por parte de los órganos de investigación,

el TEDH para desencadenar la obligación judicial de una investigación oficial eficaz. El Tribunal Constitucional ha establecido que se trata de que las sevicias denunciadas sean "aparentemente verosímiles" (sTC 224/2007, del 22 de octubre, f. j. 3).

96 STC 224/2007, del 22 de octubre, f. j. 4.

97 STC 34/2008, del 25 de febrero, f. j. 8.

98 STC 52/2008, del 14 de abril, f. j. 4.

99 STC 69/2008, del 23 de junio, f. j. 4.

100 STC 107/2008, del 22 de septiembre, f. j. 3.

101 STC 34/2008, del 25 de febrero, f. j. 9.

102 STC 224/2007, del 22 de octubre, f. j. 3. 
retrotrayéndolas en los casos en que se ha concedido el recurso de amparo y determinando así la importancia de eliminar al máximo la ocurrencia de estas conductas.

\section{CONCLUSIONES}

La prohibición contra la tortura y los malos tratos, inhumanos y degradantes es absoluta, de tal manera que resulta inadmisible bajo cualquier circunstancia. Ello ha sido demostrado por la jurisprudencia del TEDH, evolucionando con el paso del tiempo, y mediante las condenas ha logrado reducir la posibilidad de que se den estos actos, más aún hoy en día con la lucha antiterrorista. Para el caso español, el Tribunal Constitucional ha adoptado estos argumentos y en varios pronunciamientos ha determinado esta situación.

El TEDH se ha pronunciado respecto a la prohibición que se ha analizado en casos fácticos relacionados con: la expulsión (incluida la extradición, así como la denegación de asilo) a un país donde el expulsado corra el riesgo de ser condenado a la pena de muerte o a torturas; malos tratos policiales; la adopción de medidas para proteger a las personas en el ámbito de su jurisdicción; la exclusión de castigos corporales como sanción penal; y la desaparición de una persona, como trato inhumano o trato degradante en relación con sus parientes.

Frente a los tratos inhumanos y degradantes en detenciones policiales, el TEDH ha expresado que son injustificables en términos absolutos, por lo que no cabe hacer consideraciones de proporcionalidad ni ponderaciones con otros bienes jurídicos en juego. Cuando hay indicios de malos tratos policiales recae sobre la policía la carga de demostrar la corrección de su actuación.

El Reino de España ha sido condenado por el TEDH en 9 ocasiones, todas ellas por el incumplimiento de la vertiente procesal de la prohibición analizada en el presente escrito, cuestionando la pasividad de las autoridades españolas para investigar los hechos denunciados, y se han puesto de presente las recomendaciones realizadas por el Comité para la Prevención de la Tortura a España, ante las negativas del Estado para implementarlas; señalando, además, que en el caso de detenciones incomunicadas debe existir una mayor investigación de los hechos denunciados por parte del Estado. En las últimas sentencias el TEDH ha dado a entender que continuarán las condenas si no se modifica el régimen de incomunicación.

A su vez, la jurisprudencia del Tribunal Constitucional español se apoya en la jurisprudencia del TEDH para establecer una doctrina, relacionando el incumplimiento de este deber con el derecho a la tutela judicial efectiva, en el entendido de que el mismo se satisface con una investigación suficiente y efectiva de lo acontecido. Esa evaluación se realizará conforme al material probatorio con que se cuente. 
Existe una notoria evolución normativa y jurisprudencial en España, dirigida a garantizar el cumplimiento de los estándares y deberes adoptados frente a la prohibición de malos tratos y degradantes en casos de detenciones policiales. Se puede concluir que las modificaciones normativas introducidas al código de enjuiciamiento penal y el otorgamiento de recursos de amparo y de medidas en cuanto a las condiciones de detención han sido producto de las condenas impuestas por el TEDH. Por lo pronto, no obstante la eventual existencia y ocurrencia de estas situaciones fácticas, resulta meritoria la mejora normativa.

\section{REFERENCIAS}

De La Oliva Santos, A. Derecho procesal penal. Madrid: Ceura, 2003.

Evans, M. y Morgan, R. Preventing Torture. Oxford: Clarendon Press, 1998.

García Molina, P. La transposición de la Directiva 2013/48/UE en lo que respecta al derecho a la asistencia de letrado en los procesos penales a la luz del anteproyecto de ley orgánica de modificación de la ley de enjuiciamiento criminal. En Revista General de Derecho Europeo. N. ${ }^{\circ} 35,2015,1-30$.

GonzÁlez González, R. El control internacional de la prohibición de la tortura y otros tratos o penas inhumanos y degradantes. Granada: Universidad de Granada, 1998.

LóPez YAGÜEs, V. El derecho a la asistencia letrada (su ejercicio en situaciones de privación de libertad). Valencia: Universidad de Alicante, 2002.

LóPez YAGÜEs, V. La inviolabilidad de las comunicaciones con el abogado defensor. Valencia: Tirant lo Blanch, 2003.

Montero Aroca, J.; Barona Vilar, S. et al. Derecho jurisdiccional iII. Proceso penal. Valencia: Tirant lo Blanch, 2015.

Moreno Catena, V. Derecho procesal penal. Valencia: Tirant lo Blanch, 2004.

Moreno Catena, V. El enjuiciamiento de delitos de terrorismo y el derecho de defensa. En Gómez Colomer, J. L. y González Cussac, J. L. (coords.), Terrorismo y proceso penal acusatorio, Valencia: Tirant lo Blanch, 2006, 369- 398.

Moreno Catena, V. Judicial cooperation and protection of fundamental rights in the prevention and prosecution of terrorism. En RugGieri, S. (ed.), Transnational Inquiries and the Protection of Fundamental Rights in Criminal Proceedings. Berlin y Heidelberg: Springer, 2013, 139-165.

Pérez Machío, A. I. La detención incomunicada en los supuestos de terrorismo: ¿una medida lesiva de derechos humanos? En De La Cuesta, J. L. y Muñagorri, I. (dirs.), Aplicación de la normativa antiterrorista. San Sebastián: Instituto Vasco de Criminología, 2009, 167-202. 
Pino Gamero, E. El sistema de prevención de la tortura del Protocolo Facultativo a la Convención contra la Tortura. En Universitas. Revista de Filosofía, Derecho y Política. N. ${ }^{\circ} 18,2013,3-39$.

Quel López, J. y Fernández De Casadevante, C. La lucha contra la tortura (Aspectos de derecho internacional y de derecho interno español). Oñati: HAEE/IVAP, 1991.

Ramos Méndez, F. Enjuiciamiento criminal (Novena lectura constitucional). Barcelona: Atelier Libros, 2010.

Villalibre Fernández, V. Confluencia del derecho a la tutela judicial efectiva con el concepto de investigación oficial eficaz en el contexto de la prohibición de la tortura. En Foro, nueva época. Vol. 15, n. ${ }^{\circ}$ 1, 2012, 29-86. DOI: 10.5209/rev_FORO.2012.v15.n1.39582

\section{Tratados internacionales y documentos obligatorios}

Convención contra la Tortura y Otros Tratos o Penas Crueles, Inhumanos o Degradantes, adoptada y abierta a la firma, ratificación y adhesión por la Asamblea General en su Resolución 39/46, del 10 de diciembre de 1984. Entrada en vigor el 26 de junio de 1987, de conformidad con el artículo 27.

Informe ante la Comisión de Derechos Humanos en su 48. período de sesiones, 27 de diciembre de 1991 (E/CN.4/1992/17).

Informe del Comité Europeo de Prevención de la Tortura sobre la primera visita a España efectuada del 1 al 12 de abril de 1991 (СРт/Inf (96) 9).

Informe del Relator Especial sobre la Tortura, "Los derechos civiles y políticos, en particular las cuestiones relacionadas con la tortura y la detención. Doc. E/CN.4/2004/56/ Add.2, del 6 de febrero de 2004.

Informe de Humans Rights Watch, “Sentando ejemplo? Medidas antiterroristas en España". Vol. 17, n. ${ }^{\circ}$ (D) 2005, p. 30, sobre las Notas verbales de la Misión Permanente de España ante la onU.

Informe del Relator Especial sobre la Tortura, "Seguimiento dado a las recomendaciones del Relator Especial reflejadas en su informe sobre su visita a España en octubre de 2003”. Doc. E/CN.4/2006/6/Add.2, del 21 de marzo de 2006.

Informe de Amnistía Internacional, "España: Salir de las sombras. Es hora de poner fin a la detención en régimen de incomunicación”, 2009 (EUR 41/001/2009).

Quinto informe periódico de España, Comité de la Tortura, $43 .^{\circ}$ periodo de sesiones, de 5 de junio de 2010, 76 (Doc. СAT/C/SR.914).

\section{Jurisprudencia del Tribunal Europeo de Derechos Humanos}

El Caso Griego, 24 de enero de 1968.

Caso Irlanda c. Reino Unido. Sentencia del 18 de enero de 1978. 
Caso X e Y c. Países Bajos. Sentencia del 26 de marzo de 1985.

Caso Ribitsch c. Austria. Sentencia del 4 de diciembre de 1995.

Caso Stubbings y otros c. Reino Unido. Sentencia del 22 de octubre de 1996.

Caso Aksoy c. Turquía. Sentencia del 18 de diciembre de 1996.

Caso Güle.c. Turquía. Sentencia del 27 de julio de 1998.

Caso A c. Reino Unido. Sentencia del 23 de septiembre de 1998.

Caso Assenov y otros c. Bulgaria. Sentencia del 28 de octubre de 1998.

Caso Labita c. Italia. Sentencia del 6 de abril de 2000.

Caso Sevtap Veznedaroglu c. Turquía. Sentencia de 11 de abril de 2000.

Caso Timurtaş c. Turquía. Sentencia del 13 de junio de 2000.

Caso Salman c. Turquía. Sentencia del 27 de junio de 2000.

Caso KudBa c. Polonia. Sentencia del 26 de octubre de 2000.

Caso Çiçek c. Turquía. Sentencia del 27 de febrero de 2001.

Caso Keenan c. Reino Unido. Sentencia del 3 de abril de 2001.

Caso Z y otros c. Reino Unido. Sentencia del 10 de mayo de 2001.

Caso Papon c. Francia. Sentencia del 7 de junio de 2001.

Caso Indelicato c. Italia. Sentencia del 18 de octubre de 2001.

Caso Pretty c. Reino Unido. Sentencia del 29 de abril de 2002.

Caso Orhan c. Turquía. Sentencia del 18 de junio de 2002.

Caso E y otros c. Reino Unido. Sentencia del 26 de noviembre de 2002.

Caso Van der Ven c. Países Bajos. Sentencia del 4 de febrero de 2003.

Caso M. C. contra Bulgaria. Sentencia del 4 de diciembre de 2003.

Caso Kmetty c. Hungría. Sentencia del 16 de diciembre de 2003.

Caso Assanidze c. Georgia. Sentencia del 8 de abril de 2004.

Caso Barbu Anghelescu c. Rumania. Sentencia del 5 de octubre de 2004.

Caso Martínez Sala y otros c. España. Sentencia del 2 de noviembre de 2004.

Caso Gelfmann c. Francia. Sentencia del 14 de diciembre de 2004.

Caso Mikheyev c. Rusia. Sentencia del 26 de enero de 2006. 
La prohibición de tratos inhumanos y degradantes en las detenciones policiales...

Caso Okkali c. Turquía. Sentencia del 17 de octubre de 2006.

Caso Mammadov (Jalaloglu) c. Azerbaiján. Sentencia del 11 de enero 2007.

Caso Zeynep Özcan c. Turquía. Sentencia del 20 de febrero de 2007.

Caso Miembros de la Congregación de Testigos de Jehová de Gldani c. Georgia. Sentencia del 3 de mayo de 2007.

Caso Stefan Iliev c. Bulgaria. Sentencia del 10 de mayo de 2007.

Caso San Argimiro Isasa c. España. Sentencia del 28 de septiembre de 2010.

Caso Beristain Ukar c. España. Sentencia del 8 de marzo de 2011.

Otamendi Egiguren c. España. Sentencia del 16 de octubre de 2012.

Caso Etxebarria Caballero c. España. Sentencia del 7 de octubre de 2014.

Caso Ataun Rojo c. España. Sentencia del 7 de octubre de 2014.

Caso Arratibel Garciandía c. España. Sentencia del 5 de mayo de 2015.

Caso Beortegui Martínez c. España. Sentencia del 31 de mayo de 2016.

Caso Igor Portu y Mattin Sarasola c. España. Sentencia del 13 de febrero de 2018.

\section{Jurisprudencia Tribunal Constitucional español}

Sentencia STC $7 / 2004$, del 9 de febrero de 2004

Sentencia STC 224/2007, del 22 de octubre.

Sentencia STC 034 de 2008, del 25 de febrero.

Sentencia stc 052/2008, del 14 de abril.

Sentencia STC 063/2008, del 26 de mayo.

Sentencia STC 069/2008 del 23 de junio.

Sentencia STC 107/2008, del 22 de septiembre.

Sentencia STC 123/2008, del 20 de octubre.

Sentencia STC 040/2010, del 19 de julio.

Sentencia STC 063/2010, del 18 de octubre.

Sentencia STC 130/2016, del 18 de julio.

Sentencia STC 39/2017, del 24 de abril. 